\title{
Retraction Note: Proofs to one inequality conjecture for the non-integer part of a nonlinear differential form
}

Mei Chen ${ }^{1 *}$

The original article can be found online at https://doi.org/10.1186/ s13660-017-1463-3

*Correspondence: m.chen941106@aliyun.com

'School of Statistics and Mathematics, Zhongnan University of Economics and Law, Wuhan, 430073, China

\section{Retraction note}

The Editors-in-Chief have retracted this article because it shows significant overlap with an article by different authors that was simultaneously under consideration [1] and a previously published article [2]. Additionally, the article shows evidence of peer review manipulation. The author has not responded to correspondence regarding this retraction.

\section{Publisher's Note}

Springer Nature remains neutral with regard to jurisdictional claims in published maps and institutional affiliations.

Published online: 20 January 2021

\section{References}

1. Wang, Y., Mu, J.: An extension of the mixed integer part of a nonlinear form. J. Inequal. Appl. 2017, 170 (2017). https://doi.org/10.1186/s13660-017-1440-x

2. Lai, K.: The integer part of a nonlinear form with integer variables. J. Inequal. Appl. 2015, 357 (2015). https://doi.org/10.1186/s13660-015-0874-2
C The Author(s) 2021. This article is licensed under a Creative Commons Attribution 4.0 International License, which permits use sharing, adaptation, distribution and reproduction in any medium or format, as long as you give appropriate credit to the original author(s) and the source, provide a link to the Creative Commons licence, and indicate if changes were made. The images or other third party material in this article are included in the article's Creative Commons licence, unless indicated otherwise in a credit line to the material. If material is not included in the article's Creative Commons licence and your intended use is not permitted by statutory regulation or exceeds the permitted use, you will need to obtain permission directly from the copyright holder. To view a copy of this licence, visit http://creativecommons.org/licenses/by/4.0/ 